\title{
Słowo gra znaczy świat. Przestrzeń gry wideo w kognitywnej teorii narracji
}

Krzysztof M. Maj 


\section{Słowo gra znaczy świat. Przestrzeń gry wideo w kognitywnej teorii narracji}

Krzysztof M. Maj

TEKSTY DRUGIE 2017, NR 3, S. 192-209

DOI: 10.18318/td.2017.3.11

Can there be a virtual life without a virtual world capable of being inhabited?

Paul Ricœur, The Rule of Metaphor

\section{Wprowadzenie}

Co jest w grą ${ }^{1}$ w świecie Tamriel? A może ściślej: co jest ro zg ry w a n e w The Elder Scrolls V: Skyrim? Przygody

1 Z uwagi na narratologiczną orientację tego artykułu nie rozważam tu różnic pojęciowych między "grą", "grą wideo" a "grą komputerową", o których zacieraniu w polskim dyskursie piszą krytycznie chociażby Katarzyna Marak i Miłosz Markocki w książce Aspekty funkcjonowania gier cyfrowych we współczesnej kulturze (Wydawnictwo Naukowe UMK, Toruń 2016, s. 47-48). W tekście termin "gra wideo" (dominujący $\mathrm{w}$ badaniach narratologicznych) będzie konsekwentnie używany w znaczeniu możliwie najszerszym i zgodnym z jego etymologią (video, videre), natomiast kategoria „gry komputerowej" pojawi się jedynie przypadkach szczególnych, wymuszanych uzusem (jak w nazwie cRPG, czyli computer role-playing game, niemożliwej do oddania w polszczyźnie inaczej niż jako „komputerowa gra fabularna” niezależnie od tego, czy mowa o wydaniu na komputery stacjonarne czy konsole).

\author{
Krzysztof M. Maj \\ - mgr, doktorant \\ w Katedrze Antro- \\ pologii Literatury \\ i Badań Kulturowych \\ Wydziału Polonistyki \\ Uniwersytetu Jagiel- \\ lońskiego; fundator \\ i członek zarządu \\ Ośrodka Badawczego \\ Facta Ficta (facta- \\ ficta.org); redaktor \\ naczelny czasopisma \\ popularnonauko- \\ wo-artystycznego \\ "Creatio Fantastica” \\ (creatiofantastica. \\ com); autor książki \\ Allotopie.Topografia \\ światów fikcjonalnych \\ (2015).
}


protagonisty, Laat Dovahkiina, Ostatniego Zrodzonego ze Smoków? Jego życie, jedzenie, spanie, jazda konno, słuchanie muzyki, nauka w Akademii Zimowej Twierdzy, flirt z gildią złodziei w Pękninie, przeczesywanie podziemi Dwemerów w poszukiwaniu zaginionej wiedzy i skarbów? A może główny wątek fabularny, odyseja Dovahkiina przez wszystkie krainy Skyrim aż do legendarnego Sovngardu, gdzie wraz z największymi bohaterami legend przychodzi się mu (a zarazem i graczowi) zmierzyć z niepokonanym Alduinem, Pożeraczem Światów? Odpowiedzi na te pytania przynoszą refleksję krańcowo odmienną, tworzą bowiem obraz nie tyle gry, ile narracji fantasy, przesyconej encyklopedyczną wiedzą z wyobrażonego świata. Jedyną rozgrywaną relacją w TESV: Skyrim jest związek gracza i protagonisty: wcielenie się w Dovakhiina jest bowiem pierwszym przejawem n i e nat u ral n o ś c i narracji.

Początkowo imersja ${ }^{2} \mathrm{w}$ świat gry przebiega w modelowej zgodności z retoryką portal-quest fantasy ${ }^{3}$ - protagonista, przybyły z niezdefiniowanego „zewnątrz", budzi się pośród rozrzedzających się mgieł, na wozie z dwoma mężczyznami schwytanymi przez gwardię Gromowładnych za nielegalne przekroczenie granicy Skyrim. Narracja prowadzona jest więc, podobnie jak w większości postmodernistycznych powieści fantastycznych, in medias res, wprowadzając odbiorcę w realia świata poprzez zwykłą rozmowę z jego mieszkańcami. Gdy jednak Dovakhiinowi przychodzi odpowiedzieć na podstawowe pytanie egzystencjalne - „kim jesteś?"“4 - gra otwiera interfejs, dzięki któremu możliwe staje się rozegranie odpowiedzi tworzącej narrację o sobie samym jako innym ${ }^{5}$ przy jednoczesnym uruchomieniu typowego dla

2 Pojęcia tego używam w zgodzie z jego definicją jako redukcji dystansu poznawczego między światem gry a światem rzeczywistym, zaproponowaną w artykule: K.M. Maj, Czas światoodczucia. Imersja jako nowa poetyka odbioru, "Teksty Drugie” $2015 \mathrm{nr} 3$.

3 Jak definiuje ten tryb światotwórczo-retoryczny Farah Mendlesohn, "w portal-quest fantasy charakterystyczna jest droga protagonisty od przyziemnego życia (w którym to, co fantastyczne, o ile w ogóle jest uświadamiane, pozostaje raczej odległe i nieznane, lub przynajmniej nieznane protagoniście) ku bezpośredniemu kontaktowi z fantastycznością, aż do momentu, w którym możliwe staje się przewartościowywanie świata dzięki wkroczeniu do fantastycznego dominium". Przekład własny za: F. Mendlesohn Rhetorics of fantasy, Wesleyan University Press, Middletown 2008.

The Elder Scrolls V: Skyrim, Bethesda Game Studios 2011 [PC].

5 Używam tej frazy za słynną książką Paula Ricœura O sobie samym jako innym (przeł. B. Chełstowski, PWN, Warszawa 2003). Wątek ten rozwinął Michał Kłosiński w referacie On myself as the Other in Video Games, wygłoszonym podczas międzynarodowej konferencji "GamesLit” 19 
komputerowych gier fabularnych (cRPG) kreatora postaci. Równocześnie jednak, ponieważ proces dostosowania niezwykle szczegółowych parametrów rasy, płci, cielesności i aparycji postaci przebiega w sposób nieproporcjonalnie długi do średniego czasu potrzebnego do sformułowania odpowiedzi na pytanie „kim jesteś?” (postawionego, oczywiście, poza dyskursem filozoficznym) - w narracji pojawia się dysonans, określany w groznawstwie mianem „ludonarracyjnego" i ufundowany na powtarzanej przez Gonzalo Frascę tezie o rozbieżności reprezentacji i symulacji ${ }^{6}$. Należy jednak pamiętać, że źródło tego terminu nie jest naukowe, ponieważ został on użyty po raz pierwszy w 2007 roku przez dyrektora kreatywnego firmy LucasArts, Clinta Hockinga ${ }^{7}$, następnie zaś podchwycony przez innych producentów gier, a za nimi - ich badaczy. Nie jest to fortunna kolej rzeczy przede wszystkim dlatego, że negatywnie wartościuje tę cechę narracji, która w poetyce postmodernistycznej stanowi o subwersywności reprezentacji - być może odpowiedź na pytanie „kim jesteś?” nie jest prosta, być może właśnie jest fundamentalna (i wymaga przemyślenia) dlatego, że nie determinuje ani nie określa w żaden sposób a d r e s a t a tego pytania. W słynnym zakończeniu gry Assassin's Creed 2: Brotherhood Minerwa zwraca się bezpośrednio do gracza, protagonistę narracji, Ezia Auditore da Firenze, zbywając słowami „Nie chcę mówić do ciebie, lecz przez ciebie"8 - i tym samym wyraziście precyzując adresata parabazy. Seria Assassin's Creed sprzyja jednak użyciu parabazy ze względu na to, że - podobnie jak w teatrze - odbiorca śledzi narrację z perspektywy trzecioosobowej, postrzegając świat gry jako mise-en-scène, natomiast domyślny dla TESV: Skyrim widok z perspektywy pierwszoosobowej

listopada 2016 roku w Krakowie. Abstrakt wystąpienia znajduje się na stronie: https://gameslit16.wordpress.com/on-myself-as-the-other-in-video-games/ (30.11.2016).

6 Warto pamiętać, że Frasce intelektualnie nie udaje się wykroczyć - podobnie jak, niestety, wielu ludologom - poza strukturalizm, co ma swoją pozytywną stronę (zwalnia bowiem ponowocześnie zorientowanego teoretyka literatury od dyskutowania większości przypadków ponownego odkrywania koła przez ludologię), jednak równocześnie i negatywną, ponieważ pogłębia rozziew między teorią literatury i kultury postrzegającą narrację jako sposób wyrażania tożsamości, a odłamem ludologii utrzymującym, że narracja jest jedynie "jedną z form strukturowania reprezentacji [narrative is a form of structuring representation]". Por. G. Frasca Simulation versus Narrative. Introduction to Ludology, w: The Video Game Theory Reader, ed. by M.J.P. Wolf, B. Perron, M. Consalvo, Routledge, New York, London 2003, s. 224.

7 C. Hocking Ludonarrative Dissonance in BioShock. The Problem of What the Game is About, online: http://clicknothing.typepad.com/click_nothing/2007/10/ludonarrative-d.html (30.11.2016).

8 Assassin's Creed 2: Brotherhood, Ubisoft Montreal 2010 [PC]. 
tworzy iluzję bezpośredniego zaangażowania i umożliwia mimetyczną g r ę w make-beli e ve z odbiorcą?. W konsekwencji już w pierwszej godzinie gry w TES V: Skyrim gracz nie tyle sam gra w grę, ile jest przez nią samą rozgrywany - i imersji w jej świat dokonuje dopiero po przyjęciu reguł owej gry, które, co istotne, nie mają nic wspólnego z mechaniką, sterowaniem ani nawet konwencjonalnie przyjętymi stylami rozgrywki w innych produkcjach reprezentujących gatunek komputerowej gry fabularnej (cRPG). Jest to bowiem gra w fikcję, której bohaterem jest nie gracz, a Laat Dovahkiin, którego rasę, płeć, cielesność i aparycję można kształtować jedynie z wykorzystaniem opcji z predefiniowanej puli dopuszczanych przez realia świata możliwości.

Co jednak, jeśli gracz nie zechce przyjąć reguł gry i zapragnie grać wbrew nim? Jedna z setek dostępnych modyfikacji do TES V: Skyrim umożliwia chociażby podmianę tekstur kluczowych dla fabuły smoków na modele lokomotywy z brytyjskiego serialu animowanego Tomek i przyjaciele - co oczywiście wywołuje (poza zamierzonym efektem komicznym) dysonans estetyczny zarówno z artystyczną wizją krainy Skyrim, pełną zimnych barw i surowo ciosanych modeli lokacji czy postaci, jak i allonordyckimi ${ }^{10}$ realiami świata. Gdy jednakże w postmodernistycznej powieści Trojka Stepana Champana przemierza pustynię w blasku trzech fioletowych słońc brontozaur Naomi, jeep Alex i Meksykanka Eva - wówczas głosy o niespójności świata ustępują analizie awangardowych technik narracyjnych i światotwórczych, składających się na to, co określa się - również w odniesieniu do prozy Raymonda Federmana - surfikcyjnością ${ }^{11}$. Problem z odbiorem nienaturalnej narracji w grze, inkoherencją świata lub potocznie rozpoznawanym dysonansem ludonarracyjnym nie musi zatem wiązać się ze swoistością gry jako medium, lecz może być konsekwencją odgórnie przyjętej p o e ty ki. W przypadku TES V: Skyrim nie ma wątpliwości, że jest to światotwórcza narracja fantastyczna, przy której projektowaniu ogromny nacisk położono na wiarygodne

9 Więcej na ten temat: A. Łebkowska Między teoriami a fikcją literackq, Universitas, Kraków 2001, s. 225.

Przedrostkiem allo- proponuję opatrywać wszystkie allotopijne światy korzystające z historycznych encyklopedii (przykładowo świat określany potocznie - i nieprecyzyjnie, czego dowodem pojęcia alternatywne w rodzaju gaslamp fantasy czy retrofuturyzmu - mianem steampunkowego, byłby wówczas allowiktoriański). Więcej na ten temat: K.M. Maj Allotopie. Topografia światów fikcjonalnych, Universitas, Kraków 2015, s. 227-253.

11 Tamże, s. 162. 
odwzorowanie obcej rzeczywistości i jej jednoczesną alokację w wykraczającym poza jego ramy diegetyczne uniwersum innych gier z serii oraz w wykraczającym poza jego ramy topograficzne uniwersum Tamriel. To właśnie dzięki charakterystycznym wyróżnikom poetyki fantastycznej, na czele z wymienianą przez Rafała Kochanowicza „wtórną konkretyzacją ideowo-estetyczną"12, produkcja Bethesdy może stać się de facto platformą umożliwiającą graczom współtworzenie własnych narracji i twórcze modyfikowanie kodu gry zgodnie z prosumpcyjnym stylem odbioru typowym dla kultury konwergencji, zachęcającej do „e mo c jo na ln e go z a a ng ażo wa ni a [wyróż. - K.M.M.] w produkt”13. Aby jednak uniknąć pisania o grach wideo (i w ogólności „nowych" mediach) uprzywilejowującym językiem kapitalistycznym i neoliberalnym, który tylko iluzorycznie wyróżnia je na tle od dawna urynkowionej literatury (i tzw. starych mediów), warto przemyśleć ideę owego „emocjonalnego zaangażowania” z perspektywy postklasycznej teorii fikcji i narracji - a przede wszystkim zastanowić się nad źródłami rosnącej frekwencji użycia kategorii świata czy uniwersum w odniesieniu do gier.

\section{Gra między światami}

W artykule The Worldness of Everquest: Exploring a 21st Century Fiction Lisbeth Klastrup sformułowała tezę, że jakkolwiek w ostatnich latach systematycznie rośnie ilość literatury poświęconej analizie światów gier wideo (gameworlds), tak badania te wciąż pomijają fenomen złożonego doświadczenia świata gry jako właśnie ś w i a t a ${ }^{14}$. Według Klastrup tymczasem to właśnie specyficznie pojęta ś wi a to w o ś ć świata gry byłaby głównym powodem, dla którego w studiach groznawczych nie należałoby rezygnować z wykorzystywania nomenklatury wypracowanej w XX-wiecznych teoriach fikcji, z przytaczaną już Waltanowską grą w make-believe na czele. Jak uzasadnia sama badaczka:

12 R. Kochanowicz Kulturotwórcza rola uniwersów fantastycznych na przykładzie gier komputerowych z serii "The Elder Scrolls", w: Literatura i kultura popularna: Badania, analizy, interpretacje, red. A. Gemra, Pracownia Literatury i Kultury Popularnej oraz Nowych Mediów, Wrocław 2015, S. 209.

P. Siuda Kultury prosumpcji. O niemożności powstania globalnych i ponadpaństwowych społeczności fanów, Aspra. Warszawa 2012, s. 35.

14 L. Klastrup The Worldness of EverQuest. Exploring a 21st Century Fiction, "Game Studies" 2009 Vol. 9, Issue 1, online: http://gamestudies.org/og01/articles/klastrup, par. 2 (24.11.2016). 
Podążając za Tzvetanem Todorovem, utożsamiającym poetykę z koncentracją na ogólnych i unikatowych właściwościach gatunków narracyjnych, czyli właśnie ich literackości ${ }^{15}$, zdefiniowałam badania nad „światowością” jako „systematyczne studia nad wirtualnymi światami jako wirtualnymi światami", z uwzględnieniem procesu analizy oraz formułowania charakterystycznych dla nich ogólnych prawidłowości. Dlatego też szczególnie istotne jest rozumienie „światowości” na dwóch wzajemnie ze sobą powiązanych płaszczyznach. O światowości można zatem myśleć albo, na bardzo ogólnym poziomie, jako o pewnej liczbie istotnych cech charakterystycznych dla wszystkich światów, albo, na poziomie bardziej szczegółowym, jako o szeregu cech charakterystycznych dla konkretnego świata, odzwierciedlających się w sposobie, w jaki ogólne właściwości wszystkich światów mogą być wprawiane w ruch i przekształcane zarówno przez realia raz stworzonego świata, jak i funkcjonujących w jego granicach graczy. ${ }^{16}$.

Inspiracją dla tak - w gruncie rzeczy - formalistycznej definicji „światowości" miała być dla Klastrup doskonale znana teorii literatury kategoria literackości jako zespołu właściwości swoistych dla literatury, „tego, co czyni dany utwór dziełem literackim", jak pisał na długo przed Tzvetanem Todorovem, wymienianym przez Klastrup jako główne źródło inspiracji, Roman Jakobson ${ }^{17}$. Trop literackości mógłby być skądinąd w badaniach nad „światowością" światów gier wideo o tyle inspirujący, że Jakobson literackość wiązał przecież z dominantą funkcji estetycznej, a po nim, jak przypomina Henryk Markiewicz $^{\mathbf{1 8}}$, zaczęto kojarzyć ją także - np. we Wstępie do badań nad dziełem literackim Manfreda Kridla z 1936 roku - z fikcjonalnością świata przedstawionego. Klastrup jednakże nie decyduje się na powrót do metodologii

15 T. Todorov The Poetics of Prose, tans. R. Howard, Blackwell, Oxford 1977.

16 W oryginale: „I defined the study of «worldness» as the «systematic study of virtual worlds as virtual worlds» [...]. Following, it is important to understand that the concept of worldness is applicable on two levels which continuously inform each other: we can speak of worldness on a very abstract level as a number of essential aspects applicable to all worlds and on a specific level as the defining characteristics of an individual world, reflected in the way the general properties are set into motion and transformed by the world once implemented and by its players". Tamże, par. 3 .

R. Jakobson Nowiejszaja russkaja poezija, Tip. „Politika”, Praga 1921, s. 11. 
formalistycznej - jakkolwiek byłaby ona nieczytelna z zachodniej perspektywy, znającej osiągnięcia formalizmu rosyjskiego co najwyżej z przekazów Todorova - i zwraca się w kierunku poetyki doświadczenia. Zwrot ten jest o tyle ważny, że daje nadzieję na rezygnację z traktowania gry wideo jako autonomicznego systemu, kodującego swoją strukturę w sposób umożliwiający wyprowadzenie z niej właściwości uniwersalnych - co odbywałoby się w zgodzie z opisywaną przez Ryszarda Nycza tendencją do odwrotu od traktowania przedmiotów badań jako zewnętrznych i autonomicznych „hipostaz pozbawionych empirycznego osadzenia" ${ }^{\prime 9}$.

Zidentyfikowanie zatem „światowości" świata jedynie z wyabstrahowanym zespołem cech definiujących światy jako twory o odpowiednim wysyceniu enigmatyczną „światowością” powielałoby ten sam błąd, co zdyskredytowane już marzenia narratologii strukturalnej o opracowaniu skończonej puli schematów fabularnych w ramach utopijnej wizji poetyki uniwersalnej. Realizowany przez Nycza projekt poetyki doświadczenia postuluje tymczasem powrót do jej „bardziej empirycznego pojmowania jako wi e d zy [wyróż. - K.M.M.] o rzeczywistych (zrealizowanych), formalnych środkach (formach i sposobach) organizacji doświadczeniowo-wyobrażeniowego materiału twórczego"20 , konweniujący z pokrewnymi obserwacjami w kognitywnej teorii narracji, czyniącej wiedzę, poznanie i percepcję głównym obszarem swego zainteresowania. Tego rodzaju epistemologiczna wykładnia narracyjności stoi w oczywistej sprzeczności z wcześniejszymi definicjami proponowanymi przez strukturalistyczną i formalistyczną szkołę teorii literatury i narracji - jednak jest już w pełni zgodna z wykładnią kognitywną i postklasyczną ${ }^{21}$. We wprowadzeniu do książki Narrative across Media: The Languages of Storytelling Marie-Laure Ryan wprost wręcz stwierdza, że główną rolą tekstu narracyjnego w tym ujęciu jest „kreacja świata i zaludnienie go postaciami i przedmiotami", a także otwarcie na konkretyzację w postaci „zezwolenia na mentalną rekonstrukcję [wyróż. - K.M.M.] interpretacyjnej sieci celów, planów, związków przyczynowych i psychologicznych

R. Nycz Antropologia literatury - kulturowa teoria literatury - poetyka doświadczenia, "Teksty Drugie" $2007 \mathrm{nr}$ 6, s. 37. Tamże, s. 41.

Zob. A. Nünning Narratology or Narratologies? Taking Stock of Recent Developments, Critique and Modest Proposals for Future Usages of the Term, w: What is Narratology? Questions and Answers Regarding the Status of a Theory, ed. by T. Kindt, H.-H. Müller, Walter de Gruyter, Berlin-New York:2003, s. 250. 
motywacji kształtujących się wokół narracji”22 , które dopiero po spełnieniu warunku spójności i zrozumiałości mogą się ukonkretnić w fabułę. W skład narracyjnej reprezentacji - kształtującej się w tym ujęciu, zgodnie z konkluzjami szkoły estetyki odbioru z Konstancji, w interakcji czytelnika z tekstem - wchodzą zatem zdaniem Ryan: scenografia (setting) usytuowany w określonym continuum czasoprzestrzennym, postaci (characters) go zamieszkujące i rezultaty ich działań, składające się na wydarzenia fabularne (plot), które wreszcie wywierają wpływ na globalne zmiany w świecie. Dopiero z tej perspektywy widać, jak bardzo absurdalnie musi brzmieć teza Fraski, zgodnie z którą właśnie scenografia (setting), postaci (characters) i wydarzenia fabularne (events) mają w grach wideo (w odróżnieniu od tekstów - czy może raczej struktur - literackich) „nie być uwspólniane przez ramę narracyjną"23. Błąd popełniony przez urugwajskiego badacza polega zatem nie tylko na nieuwzględnieniu czterdziestu lat filozoficzno- i teoretycznoliterackich studiów nad narracyjnością, ale także braku zrozumienia dla różnicy między mimesis procesu a mimesis wytworu. Nie jest rzeczą przypadku, że przeważająca większość gier wideo tworzy reprezentacje zgodnie z regułami poetyki fantastycznej, a nie realistycznej - co niejako retroaktywnie umotywowało używanie terminu serious games w odniesieniu do produkcji „poważnych”, roztrząsających "prawdziwe” dylematy współczesności i mających „inny cel poza samą rozgrywką" ${ }^{24}$. Ów wartościujący człon terminu - mianowicie przymiotnik

M.-L. Ryan, Introduction, w: Narrative across Media: The Languages of Storytelling, ed. by M.-L. Ryan, University of Nebraska Press, Lincoln-London 2004, S. 9.

23 W kontekście: "Of course, we need a better understanding of the elements that games do share with stories, such as characters, settings, and events. Ludology does not disdain this dimension of video games but claims that they are not held together by a narrative structure". G. Frasca Simulation versus Narrative..., s. 222.

24 Co interesujące, badacze zajmujący się tymi grami w przedziwny sposób unikają pogłębionej refleksji nad motywacjami stojącymi za ukuciem terminu. Piotr Sterczewski - próbując tłumaczyć motywacje autorów najważniejszej (może dlatego, że wciąż jedynej) książki poświęconej w całości serious games, autorstwa Davida Michaela i Sande Chen - broni terminu, twierdząc, że „określenie «serious» nie oznacza koniecznie poważnego tonu samej gry, odnosi się przede wszystkim do prymarnego celu jej powstania, ale nie warunkuje jej treści" (por. P. Sterczewski Czytanie gry. O proceduralnej retoryce jako metodzie analizy ideologicznej gier komputerowych, „Teksty Drugie” 2012 nr 6, s. 218). Równocześnie jednak trudno nie zauważyć, że „poważny cel” jest zarazem mało przekonującą motywacją jakiejkolwiek działalności artystycznej, ponieważ słowo to występować może co najwyżej w rejestrze publicystycznym - z perspektywy teoretycznoliterackiej czy filozoficznej „poważność” ma bowiem w sobie tyle samo pojęciowej nośności, co „literackość" czy „światowość”. Oczywiście metodologiczna dysfunkcyjność terminu nie jest winą studiujących serious games badaczy - tak jak nie jest winą badaczy fantastyki 
„poważny” (serious) - powinien budzić zaniepokojenie w tym samym stopniu, co każda inna próba dezawuowania poetyki fantastycznej jako tej „niskoartystycznej" czy każda próba podtrzymywania dychotomii między kulturą wysoką a „masową”, wbrew zgodzie na dekonstrukcję wszystkich pozostałych opozycji binarnych w ponowoczesności. Z perspektywy teoretycznoliterackiej konieczne staje się tedy oddzielenie osobistych idiosynkrazji, zwłaszcza tych ufundowanych na badawczej hipokryzji i - w znacznej mierze - niewiedzy, od wnikliwej analizy mechanizmów, odpowiednio, re p re z e n t a c ji rzeczywistości znanej i preze nta cji rzeczywistości nieznanej. Gry z nurtu serious games - w sposób, co istotne, bardzo zbliżony do reportaży, intymistyki czy biografistyki - re prezentują rzeczywistość, koncentrując się na p raw d o p o d o b ny m (veri simile) przedstawieniu, przykładowo, wydarzeń historycznych, problemów społecznych, motywacji psychologicznych czy krytyki politycznej. Natomiast gry spoza nurtu serious games określane często - co niezmiernie zaskakujące $\mathrm{z}$ perspektywy historii literatury, w tym zwłaszcza literatury fantastycznej - „grami głównego nurtu" ${ }^{25}$ w znacznie większym stopniu prezentują inną, obcą lub nieznaną rzeczywistość, dbając o wi a rygo d n o ść przedstawienia (pithane phantasia) ${ }^{\mathbf{2 6}}$. Oznacza to, że stopień zaawansowania światotwórczego, rozumiany jako większy udział wyobraźni w wieloparametrowej kreacji świata poprzedzającej narratywizację zdarzeń fabularnych, będzie nieporównanie wyższy właśnie w grach spoza nurtu serious games - podobnie zresztą, jak w przypadku jakichkolwiek innych mediów realizujących się w poetyce fantastycznej, od literatury przez seriale i filmy aż po komiksy i animacje. Ściśle tę właśnie retorykę krytykowała wybitna znawczyni narracji postmodernistycznych, Linda Hutcheon, określając ją mianem „tradycyjnego realizmu”, któremu miałaby patronować Platońska mimesis wytworu, zgodnie z którą należałoby w obrębie danego przedstawienia: „identyfikować wytwory podlegające [w nim - K.M.M.] imitacji (bohaterowie, zdarzenia czy lokacje [characters, action, settings - K.M.M.])

semantyczna pustka pojęcia w rodzaju gaslump fantasy - jednak powinna być dekonstruowana jako przejaw paradygmatycznego dyskursu stojącego za wartościowaniem poetyki realistycznej jako w większym stopniu sprzyjającej edukacji i wpajaniu wartości, aniżeli poetyka fantastyczna.

Zob. np. P. Sterczewski Retoryka porażki. Semantyczne i perswazyjne funkcje przegranej w serious games, art games i grach głównego nurtu, „Homo Ludens” $2013 \mathrm{nr} 1$ (5).

26 Więcej na temat różnicy między prawdopodobieństwem (verisimilitudo) a wiarygodnością (pithane phantasia): K.M. Maj Allotopie..., s. 40-43. 
-idoszukiwać się podobieństwa do ich wzorców z rzeczywistości empirycznej, w wyłącznym celu nadania im wartości litera ckiej [wyróż. - K.M.M.] ${ }^{27}$. U Hutcheon to właśnie dykcja realistyczna, zwłaszcza oparta na stereotypie realizmu pojmowanego jako lustrzane odbicie ontologicznie pewnej rzeczywistości, jest definiowana w kategoriach głównonurtowych i paradygmatycznych - do tego stopnia, że proponuje ona pojęcie realistycznego imperializmu na określenie „zakładania r e a ln o ści [podkr. oryg. - K.M.M.] fikcyjnego referentu, przy jednoczesnym przekonaniu [...], że jeśli coś «zdarzyło się naprawdę» lub mogło zostać tak przedstawione, to tym samym się uprawomocniało i uprawdopodabniało"28. Poetyka realistyczna zatem, zgodnie z którą powstała chociażby gra Stanley Parable - tworząca m.in. reprezentację empirycznie zapoznanych realiów frustrującej pracy w korporacji - sprzyja wykorzystaniu awangardowych technik narracyjnych (przede wszystkim niewiarygodnego narratora, mise-en-abyme i pętli narracyjnej ${ }^{29}$ ) i grze z perspektywą odbioru, ponieważ nie konstruuje nowej rzeczywistości, która mogłaby zainteresować odbiorcę samą sobą.

Nie wydaje się nadużyciem sformułowanie w tym miejscu tezy, że groznawstwo wciąż nie przepracowało tej problematyki - nie precyzując stanowiska wobec mimesis, referencjalności, reprezentacji, fikcji i narracji, a w zamian koncentrując się na mechanice samej rozgrywki i jej swoistościach. Oczywiście umożliwiło to wytyczenie wyrazistych granic dla nowej dyscypliny - jednak na nieszczęście w czasach, w których wyraźnie mówi się o zaniku monodyscyplinarności i wynikającej zeń konieczności transdyscyplinarnego rozważania zjawisk kultury. Jednym z najbardziej wyrazistych przejawów tej tendencji jest sformułowany przez niemieckich narratologów postklasycznych - przede wszystkim Jana-Noëla Thona, Jensa Edera i Irinę Rajewsky - projekt narratologii transmedialnej, obejmującej przede wszystkim „te teorie narracji, które aplikowałyby się w większym stopniu do różnych mediów, aniżeli jednego konkretnego [those narratological approaches that may be applied

27 L. Hutcheon Narcissistic Narrative. The Metafictional Paradox, Wilfrid Laurier University Press, Waterloo 2013, s. 51. L. Hutcheon Metafictional Implications for Novelistic Reference, w: On Referring in Literature, ed. by A. Whiteside, M. Issacharoff, Indiana University Press, Bloomington 1987, s. 7. 
to different media, rather than to a single medium only]"30, a ponadto zachęcającej do studiowania zjawisk o charakterze $\mathrm{t} r$ a $\mathrm{n}$ s medialnym $\mathrm{w}$ tym sensie, że „manifestujących się w różnych mediach narracyjnych" ${ }^{31}$. W ujęciu tym istotne jest więc uniknięcie przemieszania porządków - narratologia transmedialna nie musi bowiem służyć wyłącznie analizie narracji czy światów transmedialnych. Przeciwnie, może zwracać uwagę na to, że w czasach, w których na świat gry wideo składa się nie tylko pojedyncza reprezentacja diegetyczna w postaci rzeczonej gry, trudno o jakiekolwiek monodyscyplinarne domknięcie i analizę z pominięciem wszystkich kodów semiotycznych, kształtujących się w obrębie konwergentnego „heterokosmosu odniesieniowego"32. Dlatego też w tej perspektywie badawczej ważne jest przyjęcie określonej definicji fikcyjnego świata, w inspiracji zarówno semantyką możliwych światów, jak i wyrastającą z części jej założeń narratologią kognitywną i transmedialną. Przyjąwszy zaś za Heterocosmica Lubomíra Doležela, że fikcyjne światy są „zbiorami niezaktualizowanych możliwych stanów rzeczy [...], udostępnianymi za pośrednictwem kanałów semiotycznych [ensembles of nonactualized possible states of affairs [...] accessed through semiotic channels]"33 - można w zasadzie porzucić długą i niewnoszącą wiele do badań dyskusję na temat domniemanych różnic między światami fikcyjnymi a światami wirtualnymi i zrehabilitować w tym kontekście zarówno kategorię fikcji, jak i narracji w studiach groznawczych. Wśród najważniejszych zalet takiego podejścia mieści się przede wszystkim ujednolicenie szeregu kategorii teoretycznych, jak chociażby wspominanej już mimetyczności czy reprezentacji, umożliwiające w następstwie podążenie drogą zaproponowaną przez Piotra Kubińskiego w książce Gry wideo. Zarys poetyki, w której opowiedział się on za polifoniczną definicją gry wideo jako „odmiany dyskursu cyfrowego czy wreszcie [...] swoistego tekstu kultury, który z jednej strony wytwarza własną poetykę i którego poetyka - z drugiej strony - oddziałuje również na inne teksty kultury"34. Najistotniejsze jednak wydaje się przede wszystkim to, że wszelkie metodologie opowiadające się za

30 I.O. Rajewsky Intermediality, Intertextuality, and Remediation. A Literary Perspective on Intermediality, „Intermédialités: Histoire et théorie des arts, des lettres et des techniques” 2005 no. 6, s. 46.

J.-N. Thon Transmedial Narratology and Contemporary Media Culture, University of Nebraska Press, Lincoln 2016, S. 14.

L. Hutcheon Metafictional Implications..., s. 8.

L. Doležel Heterocosmica. Fiction and Possible Worlds, The John Hopkins University Press, Baltimore 1998, s. 16.

P. Kubiński Gry wideo. Zarys poetyki, Universitas, Kraków 2016, s. 14 -15. 
sytuowaniem kategorii świata w centrum rozważań - nazwijmy je za Ryan światocentrycznymi ${ }^{35}$ - sprzyjają opisowi gier wideo jako medium szczególnie podatnego na niespotykane w innych mediach style odbioru i mechanizmy poznawczej partycypacji.

\section{O zamieszkiwaniu grywalnych światów ${ }^{36}$}

Frekwencja występowania pojęcia „uniwersum” w odniesieniu do światów tworzonych z wykorzystaniem narzędzi oferowanych przez poetykę fantastyczną jest równie wysoka w przypadku literatury, jak i filmów czy gier wideo - co skłania ku refleksji, czy o imersywności tych ostatnich nie przesądzają aby zjawiska niezwiązane w ogóle z interaktywnością czy wirtualnością. Choć zatem u Josepha Nechvatala imersja jest traktowana jako „nieodzowny element doświadczenia wirtualnej rzeczywistości" ${ }^{37}$, zaś u Kubińskiego związana jest z „wrażeniem niezmediatyzowanego uczestnictwa, bezpośredniej obecności w cyfrowej przestrzeni generowanej komputerowo" ${ }^{\text {, }}$, w kognitywnej teorii narracji istnieją przesłanki - opisane skrupulatnie przez Ryan w książce Narrative as Virtual Reality - do myślenia o imersji nie w kategoriach ontologicznych (jako więc obecności czy teleobecności), lecz epistemologicznych. Jeśliby mianowicie raz jeszcze nawiązać do dyskutowanych już badań Klastrup nad „światowością świata” (worldness), można byłoby zaryzykować tezę, że światowość staje się światoodczuciem w tym momencie, w którym świat jest już nie tylko postrzegany, poznawany czy odkrywany - lecz przede wszystkim od c zuwany i d oświ a d c z n n. W słynnej definicji świata narracji (storyworld) ${ }^{39} \mathrm{z}$ The Routledge Encyclopedia of Narrative Theory David Her-

35 M.-L. Ryan Transmedial Storytelling and Transfictionality, "Poetics Today” 2013 Vol. 34, No. 3, s. 383 .

Jest to gra z tytułem artykułu Michała Kłosińskiego, który rozwija tę problematykę w kontekście filozofii wirtualnych światów. Zob. tegożZamieszkiwanie wirtualnych światów „ „Śląskie Studia Polonistyczne" 2017 nr 1 (9).

J. Nechvatal Towards an Immersive Intelligence, "Leonardo" 2001 Vol. 34, No. 5, s. 417. P. Kubiński Gry wideo..., s. 51.

W polskiej recepcji narratologii kognitywnej termin ten jest tłumaczony jako „świat opowieści” czy "światopowieść", co jest zgodne jednak z potoczną, a nie teoretycznoliteracką wykładnią angielskiego story. Z uwagi z kolei na fakt, że po zwrocie postmodernistycznym w teorii literatury dąży się do jak najszerszego rozumienia kategorii narracji, „świat narracji” wydaje się fortunniej oddawać tę wiązkę znaczeniową, którą przypisuje mu Herman - albowiem „klasa modeli dyskursywnych", za jaką uważa on storyworld, w znacznym stopniu wykracza poza naj- 
man, pionier postklasycznych studiów nad narracyjnością światów, wprost wskazuje, że istotą odbioru świata jest:

nie tyle zwykłe rekonstruowanie serii wydarzeń czy zbioru bytów fikcjonalnych, ilewyobrażeniowe (emocjonalne, wewnętrzne) zamieszkanie w świecie [wyróż. - K.M.M.] w którym rzeczy mają znaczenie, poruszają, ekscytują, odrzucają, zapewniają przestrzeń dla rozrywki i smutku - zarówno dla uczestników narracji, jak i interpretatorów fabuły ${ }^{40}$.

Spostrzeżenie to jest fundamentalne w sposób szczególny dla światów gier wideo, których odbiór w żadnym razie nie ogranicza się do śledzenia i rekonstruowania biegu wydarzeń czy też gromadzenia danych na temat napotykanych postaci lub zwiedzanych lokacji. Herman oddaje tu językiem narratologii postklasycznej Barthesowską jouissance doświadczenia artystycznego - która zostaje tu jednak wyniesiona na poziom interakcji nie tylko z tekstem czy nawet tekstem kultury, ale z całym światem, wykraczającym poza k a ż d ą diegezę, niezależnie od jej medialnej reprezentacji. Co więcej, w tej samej definicji pada także teza, zgodnie z którą:

zakorzenienie narracji [stories] w światach narracji [storyworlds] prowadzi w dalekiej perspektywie ku wyjaśnieniu imersywności narracji, ich sposobu na „przenoszenie" [transport] interpretatorów w miejsca i czasy, które muszą oni zająć [occupy] celem zrozumienia narracji. ${ }^{41}$

Owa metafora przeniesienia czy - w znacznie większym stopniu - „wyobrażeniowego zamieszkania” jest kluczowa z perspektywy, z której rzadko rozpatruje się gry wideo, a mianowicie z perspektywy oikologicznej. Według

ogólniejsze nawet rozumienie opowieści czy fabuły. Herman zaznacza to zresztą sam w definicji z Routledge Encyclopedia of Narrative Theory, gdzie precyzuje, że: "generalnie rzecz ujmując, jeśliby zestawiać storyworld z pokrewnymi kategoriami fabuły [fabula] czy narracji [story], okazuje się, że najbliżej temu pojęciu do czegoś, co można byłoby nazwać ekologią narracyjnej interpretacji". D. Herman Storyworld, w: Routledge Encyclopedia of Narrative Theory, ed. by D. Herman, M. Jahn, M.-L. Ryan, Routledge, London-New York:2008, s. 570. Por. dyskusję na ten temat w: K.M. Maj Światotwórstwo w perspektywie narratologicznej, w: Literatura popularna, t. 2: Fantastyczne kreacje światów, red. E. Bartos i in., Wydawnictwo UŚ, Katowice 2014, s. 65-66.

D. Herman Storyworld, s. 570.

41 Tamże. 
Tadeusza Sławka oikologia to „nauka o domu sprzed («gotowej formy») domu"42, problematyzująca dom jako swego rodzaju miejsce przechodnie, zawsze pozostające na granicy porządku własnego i obcego (wnętrza i zewnętrza, bezpieczeństwa i niebezpieczeństwa, bezruchu i ruchu) - a jednocześnie pochodzące z porządku sprzed jakichkolwiek zaszeregowań. Oikologiczne postrzeganie domu i domostwa w dobry sposób pokazuje zgubę rozłącznego postrzegania świata pierwotnego i świata wtórnego, będące niestety leitmotivem najważniejszej monografii światotwórstwa w postaci Building Imaginary Worlds. The Theory and History of Subcreation Marka J.P. Wolfa. Opozycja ta bowiem zasadza się na przedklasycznym jeszcze przeświadczeniu o uwikłaniu wszelkiej fantastyczności w nieuchronną dychotomię znanego i nieznanego, metaforycznego „Tu” $i$ „Tam”, na którą nakłada się wspomniana wyżej za Hutcheon predylekcja teoretyków do doszukiwania się rozmaitych uprawomocnień i legitymizacji w sferze „Tu” jako pierwotnej poznawczo i z metafizycznego nadania nadrzędnej wobec każdej „sztucznej” subkreacji (czyli aktu stworzenia świata drugorzędnego, secondary world). Jak pisał o tym w Polsce o fantastyce już Andrzej Zgorzelski:

Literatura operująca jeszcze zabiegiem fantastyki [zawiera - K.M.M.] w sobie konfrontację dwóch modeli rzeczywistości - jednego, opartego na prawach świata dostępnego doświadczeniu autora i ówczesnych czytelników, oraz drugiego, prawa owe przełamującego, niespotykanego i dziwnego dla bohaterów i narratora. ${ }^{43}$

W lekturze postmodernistycznej, proponowanej przez Sławka, opozycja ta podlega dekonstrukcji u swego źródła - jako, co istotne, zakorzeniona nie tylko w literaturze (jak wskazuje jeszcze Zgorzelski w czasach, o czym warto pamiętać, w których remediacje narracji fantastycznych w filmie i grze wideo były jeszcze pieśnią przyszłości), ale w kulturze Zachodu:

Nie wiem, czy „tu” i „tam” dadzą się oddzielić; fonetyczna bliskość elementów wyrażenia "to tu, to tam" nie jest przypadkowa. Umieszczone pośrodku słowo "gdzie" jest więc niezbędne; nie tyle mediuje między

T. Sławek Gdzie?, w: Oikologia. Nauka o domu, red. T. Sławek, A. Kunce, Z. Kadłubek, Stowarzyszenie Inicjatyw Wydawniczych, Katowice 2013, s. 34.

A. Zgorzelski Wymiar przestrzeni jako ekwiwalent genologiczny w ewolucji SF, w: Fantastyka, fantastyczność, fantazmaty, red. A. Martuszewska, Wydawnictwo UG, Gdańsk 1994, s. 28. 
jednym a drugim położeniem, ile pozwala zgłosić wątpliwości co do jednoznacznego charakteru mojego umiejscowienia. „Tu ta tam”, a zatem „gdzie tam?", ale równie dobrze możemy spytać „gdzie tu?”. Można rozumieć tę wątpliwość lokalizacji jako radykalne zachwianie pojmowania przestrzeni, polegające na zakwestionowaniu wszelkiej precyzji, ale można także zastanowić się nad tym, czy „tu" i „tam" nie są ze sobą od samego początku głęboko splecione, a zatem czy da się w ogóle oddzielić je od siebie, nie dlatego że się wzajemnie unieważniają, lecz dlatego że wzajemnie się uprawomocniają. ${ }^{44}$

Zasadnicze pytanie „gdzie?”, które de facto jest najczęściej zadawanym pytaniem przez teoretyków wirtualności, zastanawiających się właśnie nad tym, gdzie jesteśmy, gdy dokonujemy interakcji ze sztucznie wykreowanym środowiskiem elektronicznym - i gdzie pozostajemy, gdy decydujemy się na przerwanie tej interakcji ${ }^{45}$. Dlatego właśnie pytanie „gdzie?" przywraca „zdolność do bycia zaskoczonym tym, czego (na pierwszy rzut oka przynajmniej) nie ogarniamy” zaś „«miejsce» i «dom» winny stać się obszarem pojawiania się owej zdolności" ${ }^{\prime 46}$. Pytając "gdzie?", stwarzamy także przestrzeń do realizacji postulatu Lubomíra Doležela, zachęcającego do „modyfikowania, konkretyzowania lub nawet zawieszania wiedzy zapośredniczonej" z ich aktualnego - jak sam to ujmuje - d o m i c ylu (łac. domicilium, 'miejsce stałego zamieszkania') podczas aktu stawania się „poznawczymi rezydentami [cognitive residents] ${ }^{147}$ - a więc z a d o m owiania - fikcyjnego świata.

Wydaje się w tym kontekście co najmniej znaczące, że w tylu grach wideo z otwartym światem pojawia się wydzielona, bezpieczna przestrzeń, która

44 T. Sławek Gdzie?, w: Oikologia, s. 8.

$45 \mathrm{Na}$ aporię tę wskazywał Michał Ostrowicki: „Człowiek, który już odszedł sprzed monitora, wydaje się wciąż pochłonięty, zanurzenie w realis powoduje, że zyskuje on drugą naturę, być może odnajduje naturę dotychczas nieznaną. W swoistym renesansie potrzeb, emocji i uczuć człowiek wyłania się przenikając przez interfejs, gdzie magistrala światłowodu prowadzi do nowego miejsca. Droga powrotna może stawać się nie zawsze chcianą koniecznością. Opustoszała realność, zakryta woalem metafizyki, zostaje osamotniona w realnym przemijaniu, a człowiek odnajduje własny świat w pochodzie elektronicznych dusz, odbywa historyczne misterium przekształcania obrazu w świat człowieka". Tegoż Człowiek w rzeczywistości elektronicznego realis. Zanurzenie, w: Wizje i re-wizje: Wielka księga estetyki w Polsce, red. K. Wilkoszewska, Universitas, Kraków 2007, s. 553.

T. Sławek Gdzie?, w: Oikologia, s. 25.

L. Doležel Heterocosmica, s. 181. 
jest albo strefą wyłączoną z działań zagrażających życiu fikcyjnej postaci (zarówno w makroskali, jak w przypadku wojny czy epidemii, jak i w mikroskali, jak w przypadku ataków potworów czy zasadzek grasantów), albo przestrzenią o s o bn ą, stwarzającą warunki do aklimatyzacji w nieznanym świecie i kształtującej się podług indywidualnych upodobań. W przywoływanym często w odniesieniu do tego zjawiska rozszerzeniu Hearthfire do The Elder Scrolls V: Skyrim przestrzeń można zadomowić w niezwykle wiarygodny sposób, w pierwszej kolejności kupując parcelę od jednego z jarlów w Skyrim, a następnie wznosząc dom siłami własnych rąk od fundamentów aż po dach $^{48}$. Twórcy dodatku umożliwili w ten sposób wzmożenie emocjonalnej więzi gracza z wznoszonym przez niego domem - pozwalając zachować mu na długo wspomnienia o tym, jak jego postać walczyła w ciemnych jaskiniach o zdobycie cennych rud metali czy pozbywała się równie cennych zasobów finansowych w celu zlecenia rozbudowy kolejnych skrzydeł budynku. Najistotniejszym elementem była jednakże możliwość zasiedlenia go i wprowadzenia się, w dodatku z rodziną i adoptowanym dzieckiem, które można było nawet w pewnym momencie obdarować zwierzątkiem do opieki. Ważne jest jednak, by traktować wszystkie te szczegóły nie jako zwykłe urozmaicenie zabawy czy powodowane względami marketingowymi przedłużenie czasu spędzonego na grze w świecie Tamriel. W początkowych partiach Oikologii pada zdanie: „Mieszkać [...] znaczy przebijać się niestrudzenie przez morze szczegółów, detalicznych historii życia ludzi i kamieni, w stronę możliwości «zamieszkiwania»"49 - i to właśnie w tej poetyce wrażliwości na akt zadomowienia i oswojenia przestrzeni w najgłębszy, afektywny sposób należałoby czytać intencje twórców Hearthfire, ostatecznie nieprzypadkowo właśnie przywołujących w tytule rozszerzenia metaforę ogniska domowego. Z tej perspektywy inaczej też przedstawia się możliwość udekorowania nowo wybudowanego domu pamiątkowymi trofeami pokonanych monstrów, układania w regałach zakupionych lub odnalezionych podczas wielu przygód książek, zawieszania na ścianach co wartościowszych elementów rynsztunku czy nawet składowania w kufrach, skrzyniach i szafach ekwipunku, którego nie mieszczą już i tak pojemne sakwy Dovahkiina. Wszystko to bowiem sprawia, że oikos ogniska domowego staje się „konstrukcją «pewną» w «niepewnym»

48 W kontekście imersji i make-believe pisałem też o tym w artykule: K.M. Maj Czas światoodczucia..., s. 384 . 
świecie"50 - i miejscem „z-gdzi e "51, z k tó r e go wyrusza się do świata i d o k tó r e go się ze świata powraca. W analogiczny sposób należałoby interpretować Podniebną Twierdzę z Dragon Age: Inkwizycji, winnicę Corvo Bianco z dodatku Krewi wino do Wiedźmina 3: Dziki gon czy nawet kokpit i dojo z Warframe - we wszystkich tych bowiem przypadkach akt dostosowywania wyglądu czy meblowania wirtualnej przestrzeni jest tożsamy z zadomowieniem i tożsamościowym zakorzenieniem w fikcyjnej przestrzeni.

Zamieszkiwalność i oikologiczna oswajalność świata gry są prawdopodobnie najlepszym argumentem na rzecz badania światów gier właśnie z perspektywy narratologii postklasycznej - bowiem mało która metodologia groznawcza pozwala na tak daleko zakrojone zapośredniczenie kulturowe samego aktu rozgrywki, różniącego się tu od aktów odbioru w innych mediach nie tyle swoistością mechaniki, zastosowanymi rozwiązaniami technologicznymi czy remediacją określonych zjawisk narracyjnych, lecz otwarciem na światotworzenie i światoodczuwanie. Równocześnie to właśnie w grach wideo rozwija się pełnozakresowo poetyka fantastyczna, zogniskowana na aktywności światotwórczej i światocentryczna w warstwie narracyjnej. Dlatego też słowo gra coraz rzadziej oznacza czystą rozgrywkę - a coraz częściej wirtualną narrację, tworzącą nie tylko fikcyjne światy i uniwersa, ale również pozwalającą na wydzielenie i oswojenie w niej przestrzeni osobnej. Na rozniecenie domowego ogniska, za którym można zatęsknić w równej mierze jak za tym, o którym zapominamy, zasiadając przed ekranem komputera.

50 T. Sławek Mapa domu, w: Oikologia, s. 79.

51 T. Sławek Gdzie?, w: Oikologia, s. 31-37. 


\section{Abstract}

\section{Krzysztof M. Maj}

JAGIELLONIAN UNIVERSITY (CRACOW)

The Word Game Means the World: The Dimension of the Video Game in Cognitive Narrative Theory

Maj outlines the main concepts of post-classical (cognitive and trans-medial) narrative theory (especially storyworld) in order to reintegrate the category of fiction and the fictional world into video game research. This integration of questions of mimeticism, representation (and its realism) or the intensity of the reception goes hand in hand with a discussion on Lisbeth Klastrup's notion of 'a world's worldness' as well as the history of theoretical and narratological concepts of perceiving the world, world-building and inhabiting fictional worlds. In the final part Maj draws on Tadeusz Sławek's oikological reflections to explore the increasingly frequent occurrence of houses and the inhabitation of virtual space in world-building video games - a phenomenon that suggests that a literary theory offers an apt perspective to tackle the most recent problems in games studies.

\section{Keywords}

world-building, post-classical narratology, fiction, representation, video games, oikology 